\title{
Regulation of hypoxic pulmonary vasoconstriction: basic mechanisms
}

\author{
N. Sommer*, A. Dietrich", R.T. Schermuly*, H.A. Ghofrani*, T. Gudermann", \\ R. Schulz*, W. Seeger*, F. Grimminger* and N. Weissmann*
}

ABSTRACT: Hypoxic pulmonary vasoconstriction (HPV), also known as the von Euler-Liljestrand mechanism, is a physiological response to alveolar hypoxia which distributes pulmonary capillary blood flow to alveolar areas of high oxygen partial pressure.

Impairment of this mechanism may result in hypoxaemia. Under conditions of chronic hypoxia generalised vasoconstriction of the pulmonary vasculature in concert with hypoxia-induced vascular remodelling leads to pulmonary hypertension. Although the principle of HPV was recognised decades ago, its exact pathway still remains elusive. Neither the oxygen sensing process nor the exact pathway underlying HPV is fully deciphered yet. The effector pathway is suggested to include L-type calcium channels, nonspecific cation channels and voltagedependent potassium channels, whereas mitochondria and nicotinamide adenine dinucleotide phosphate oxidases are discussed as oxygen sensors. Reactive oxygen species, redox couples and adenosine monophosphate-activated kinases are under investigation as mediators of hypoxic pulmonary vasoconstriction. Moreover, the role of calcium sensitisation, intracellular calcium stores and direction of change of reactive oxygen species is still under debate.

In this context the present article focuses on the basic mechanisms of hypoxic pulmonary vasoconstriction and also outlines differences in current concepts that have been suggested for the regulation of hypoxic pulmonary vasoconstriction.

\section{KEYWORDS: Hypoxia, hypoxic pulmonary vasoconstriction, lung, oxygen, oxygen sensing}

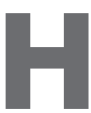

ypoxic pulmonary vasoconstriction (HPV) is a physiological self-regulatory response to alveolar hypoxia that distributes pulmonary capillary blood flow to areas of high oxygen availability. This principle, also known as the von Euler-Liljestrand mechanism, thereby optimises gas exchange at the blood-air interface $[1,2]$.

Impairment of this mechanism during pathological situations in lung or systemic disease (for example, adult respiratory distress syndrome [3] or hepatopulmonary syndrome [4]) or during anaesthesia [5], may result in insufficient oxygenation of arterial blood and poor oxygen supply to the body. Chronic hypoxia, as it occurs at high altitude or during respiratory diseases (including chronic obstructive pulmonary disease, sleep apnoea, fibrosis, failure of ventilation due to neurological diseases), may lead to general vasoconstriction of the pulmonary vasculature inducing vascular remodelling processes with subsequent right heart hypertrophy and cor pulmonale.

Due to the opposite functions of lung vessels and systemic vessels, collecting and distributing oxygen, respectively, different reactions to hypoxia have developed. Whereas most systemic vessels of adult organisms dilate during hypoxia, pulmonary vessels constrict. During embryonic development lung vessels exhibit pronounced

Previous articles in this series: No. 1: Wagner PD. The biology of oxygen. Eur Respir J 2008; 31: 887-890. No. 2: Zhou G, Dada LA, Sznajder Jl. Regulation of alveolar epithelial function by hypoxia. Eur Respir J 2008; 31: 1107-1113. No. 3: Berchner-Pfannschmidt U, Frede S, Wotzlaw C, Fandrey J. Imaging of the hypoxia-inducible pathway: insights into oxygen sensing. Eur Respir J 2008; 32: 210-217. No. 4: Lévy P, Pépin J-L, Arnaud C, et al. Intermittent hypoxia and sleep-disordered breathing: curent concepts and perspectives. Eur Respir J 2008; 32: 1082-1095. No. 5: López-Barneo J, Ortega-Sáenz P, Pardal R, Pascual A, Piruat Jl. Carotid body oxygen sensing. Eur Respir J 2008; 32: 1386-1398.

Earn CME accreditation by answering questions about the article. You will find these at the back of the printed copy of this issue or online at www.erj.ersjournals.com/current.shtml

AFFILIATIONS

*University of Giessen Lung Center Medical Clinic IIN, Justus-LiebigUniversity Giessen, Giessen, and ${ }^{\#}$ Philipps-University Marburg, Institute of Pharmacology and Toxicology, Marburg, Germany.

CORRESPONDENCE

N. Weissmann

University of Giessen Lung Center Medical Clinic II/N

Justus-Liebig-University Giessen 35392 Giessen

Germany

Fax: 496419942419

E-mail: norbert.weissmann@uglc.de

Received:

January 292008

Accepted after revision:

May 022008

STATEMENT OF INTEREST

None declared.
European Respiratory Journal Print ISSN 0903-1936 Online ISSN 1399-3003 
vasoconstriction, in order to minimise blood flow through the noninflated lungs, and to preserve the foetal circulation. After birth, pulmonary oxygenation, in concert with lung inflation, leads to vasodilation and perfusion of the lung. From the ontogenic point of view, therefore, HPV also can be seen as "normoxic pulmonary vasodilation" [6].

The present article focuses on the basic mechanisms and features of HPV, and also outlines differences in current concepts that have been suggested for the regulation of HPV. Further research will be necessary to completely elucidate the molecular pathways underlying HPV, which may serve as a basis for the development of new therapeutic strategies to treat disturbances in gas exchange caused by impaired HPV and pulmonary hypertension caused by exacerbated HPV.

\section{CHARACTERISTICS AND KINETICS OF HPV}

$\mathrm{HPV}$ is a highly conserved mechanism, present in most mammals [7-10], partially in reptiles [11] and probably even in fish [12]. Although an increase in pulmonary arterial pressure in response to alveolar hypoxia was recognised early [13, 14], it was in 1946 that von EULER and LILJESTRAND [15] suggested that ventilation-perfusion matching was the purpose of this response. Subsequently HPV was demonstrated to be present in humans, determined by a $50 \%$ increase in pulmonary arterial resistance to an alveolar oxygen partial pressure $\left(\mathrm{PA}, \mathrm{O}_{2}\right)<50 \mathrm{mmHg}(<6.66 \mathrm{kPa})$ [16]. Since then, factors modulating HPV have been identified by dissecting the mechanism of HPV using a variety of approaches including isolated organs, tissues and single cells. Modulating factors include sex, local and circulating vasoactive substances, $\mathrm{pH}$, partial pressure of carbon dioxide $[17,18]$ and red blood cells, although there was an early consensus that the mechanism itself was independent from neural [19] or humoral [20, 21] triggers.

In the isolated, buffer-perfused lung, HPV is activated at a partial pressure of oxygen $\left(\mathrm{PO}_{2}\right)<100 \mathrm{mmHg}(<13.3 \mathrm{kPa})[8$, 10]. The precapillary smooth muscle layer of the resistance vessels, located at the entrance of the acinus has been identified as the effector cell-type for HPV [22-25]. Pulmonary arterial smooth muscle cells (PASMC) contract in response to hypoxia at a $\mathrm{PO}_{2}$ of $25-50 \mathrm{mmHg}(3.33-6.66 \mathrm{kPa})$, particularly in resistance arteries, whereas smooth muscle cells from isolated cerebral arteries dilate [26, 27]. At least for acute $\mathrm{HPV}$, the sensor cell is most probably also the effector cell, although some necessity for preconditioning of these cells for contraction has been suggested. The pulmonary vasculature responds to changes in $\mathrm{PA}_{2} \mathrm{O}_{2}$ within seconds, as is assumed from a teleological point of view, since HPV has to adapt perfusion to ventilation "breath-to-breath" [8]. For sustained hypoxia (lasting several minutes to hours and sometimes in contrast to chronic hypoxic reactions in the range of days also referred to as "acute or sub-acute $\mathrm{HPV}^{\prime \prime}$ ) a temporary vasodilation has been described, followed by a secondary vasoconstrictor response. However, these kinetics are not observed in all investigations and a contribution of endothelial cells must also be taken into account [28, 29]. Sustained HPV may be of major relevance for continuous ventilation-perfusion matching and under conditions of generalised hypoxia, which results in pulmonary hypertension.

\section{SIGNAL TRANSDUCTION AND EFFECTOR MECHANISM: ABOUT CONTRACTION AND CALCIUM}

The pathways leading to contraction of the PASMCs converge in an intracellular calcium increase and include the influx of extracellular calcium and release of intracellularly stored calcium [30].

For calcium influx from the extracellular space there is evidence that both, L-type calcium channels [31, 32] and nonspecific cation channels (NSCC) are involved. In line with this suggestion, inhibition of L-type calcium channels only partially abolished HPV [33, 34], whereas inhibition of NSCC completely inhibited HPV [35-37]. Hypoxic regulation of the L-type calcium channels may be achieved by direct modulation via reactive oxygen species (ROS) or membrane depolarisation via potassium channels [38-40] and NSCCs.

Different types of potassium channels have been demonstrated to be involved in hypoxia-associated membrane depolarisation, particularly the voltage-gated potassium $\left(\mathrm{K}_{\mathrm{v}}\right)$ channels, $K_{v} 2.1, K_{v} 1.5, K_{v} 9.3$ [41-43], which have been suggested to be the "first step" in HPV. However, only partial inhibition of HPV in knockout animals suggests this may not be the sole mechanism of HPV [44]. The concept of $K_{v}$ channels being directly regulated by redox-changes has been proposed by POsT et al. [39]. The $\mathrm{K}_{\mathrm{v}}$ channels may be regulated by: 1) reducing agents [45-48], such as glutathione (GSH) [49]; 2) an associated haemoprotein; 3) membrane depolarisation; or 4) a calcium increase triggered by intracellular calcium release from intracellular stores or via NSCCs. Thus NSCCs may be key channels for hypoxic signalling, for example, in the regulation of potassium channels, of L-type calcium channels or the calcium level. The NSCCs have recently been emphasised as potential key regulators in HPV [37]. They consist of a group of store-operated and receptor-operated calcium channels (SOCs and ROCs, respectively), and their molecular identity has been revealed as transient receptor potential (TRP) channels. Certain subtypes of the TRP channels have been demonstrated to be increased in rat pulmonary arteries (PAs) after exposure to chronic hypoxia and human PASMCs in idiopathic pulmonary hypertension, suggesting a pathogenetic importance of TRP canonical (TRPC)1 and TRPC6 [50, 51]. The SOCs play a role in capacitative calcium entry (CCE), a calcium influx from extracellular space that can be induced by emptying intracellular stores, and has been shown to be activated in HPV [37, 52]. While CCE is a phenomenon observed in several types of systemic arteries, its coupling to contraction appears to be of particular importance in PAs [53], but its exact impact on HPV has not yet been resolved, especially in the face of a lack of specific experimental manipulation methods [37]. The ROCs can be activated by protein kinases and diacylglycerol. Recently, the present authors have demonstrated that this mechanism is indispensable for acute HPV, occurring within seconds to minutes, as: 1) TRPC6 knockout mice have no pulmonary vascular reactivity to hypoxia although they fully respond to nonhypoxia induced vasoconstriction; and 2) PASMCs isolated from TRPC6-deficient mice exhibit no hypoxic calcium increase and membrane current when exposed to hypoxia, in contrast to wild-type PASMCs [54]. TRPC6 may modulate intracellular calcium and membrane potential by subsequent gating of $\mathrm{K}_{\mathrm{v}}$ and L-type calcium channels. 
There is evidence that internal calcium release plays an obligatory role in hypoxic inhibition of potassium currents $[55,56]$. Although challenged by a recent study [54], an initial release of calcium from intracellular stores was suggested as a key trigger for HPV. This concept is based on studies that demonstrate an increase in intracellular calcium even after removal of extracellular calcium and release of calcium from internal stores via ryanodine-sensitive calcium stores [57] with calcium buffering of inositol triphosphate $\left(\mathrm{IP}_{3}\right)$ sensitive stores [58-60]. Debate continues regarding how they might be regulated and the observed increase of intracellular released calcium may be restricted to PASMCs of nonresistance PAs with a large diameter [54]. In other cell types, intracellular calcium stores are susceptible to redox modulation via ryanodine-sensitive receptor channels that are modulated by redox-regulating systems [61], ROS [62, 63] and cyclic adenosine diphosphate-ribose [64], and $\mathrm{IP}_{3}$ receptor channels modulated via cyclic guanosine monophosphate and reduced nicotinamide adenine dinucleotide (NADH) [65].

For sustained HPV in particular, a $\mathrm{Ca}^{2+}$ sensitisation, in addition to an increase in calcium, possibly via activation of Rho-kinase, has been suggested [66-68]. A recent point-counterpoint discussion summarised the debate regarding $\mathrm{Ca}^{2+}$ sensitisation as a further possible mechanism for HPV [69]. For sustained HPV in particular, the importance of the endothelium, the lack of correlation between tension and internal calcium concentration and the effect of inhibition of RhoA/Rho kinase are good arguments for $\mathrm{Ca}^{2+}$ sensitisation. For acute $\mathrm{HPV}$, the sensitising effects of endothelium are considered to be negligible, as acute HPV could be detected in the absence of endothelium [70-72], but Rho-kinase could also be activated in an endotheliumindependent fashion [67]. However, the debate is obscured by an absent systemic definition of preconditioning, and the lack of consensus regarding the characteristics and existence of sustained HPV in different models, and data from different laboratories. Therefore, it is not yet clear if Rho-kinase and/or other protein kinases play only a modulating, or an indispensible, role in HPV [73].

\section{THE ROLE OF ROS IN HPV}

As the modulation of the cellular redox state and alteration of ROS releasing systems have been demonstrated to affect the strength of HPV, it has been concluded that ROS or the cellular redox state may play a role in the hypoxic signalling pathway. The L-type calcium channels and intracellular calcium channels can be activated by ROS [74], and $K_{v}$ channels can be inhibited by reducing equivalents. Whereas there is wide consensus regarding the importance of ROS, two opposing scenarios are offered for ROS regulation during HPV. One concept favours $\mathrm{K}_{\mathrm{v}}$ channel modification by a reduced level of ROS as a trigger for contraction. The second concept proposes an increase in ROS during hypoxia from mitochondria or reduced nicotinamide adenine dinucleotide phosphate (NADPH)-oxidases (for review see [75-79]).

The application of oxidants and antioxidants has been helpful in understanding the reactivity of the pulmonary vascular system with regard to HPV. Hydrogen peroxide induces pulmonary vasoconstriction during normoxia [80-82], but antioxidants also cause constriction of isolated vessels by inhibition of $K_{v}$ channels [48]. Such discrepancies may result from the possibility that the applied agents reach only parts of the vasoreactive pathways without necessarily affecting the physiological pathway activated during hypoxia. This view is supported by the observation that oxidants $[48,82,83]$ as well as antioxidants [84] inhibited HPV. Detailed pharmacological interventions provided evidence for both an upregulation as well as for a downregulation of superoxide, and subsequently $\mathrm{H}_{2} \mathrm{O}_{2}$, as the underlying pathway of $\mathrm{HPV}[85,86]$. An elegant study demonstrated that overexpression of glutathione peroxidase, cytosolic or mitochondrial catalase attenuated the hypoxiainduced increase in ROS signalling and intracellular calcium, whereas mitochondrial matrix-targeted manganese superoxide dismutase (which decreases superoxide, but increases $\mathrm{H}_{2} \mathrm{O}_{2}$ ) augmented intracellular calcium [87]. This suggests that superoxide production leading to $\mathrm{H}_{2} \mathrm{O}_{2}$ being released from mitochondria, contributes to the hypoxia-induced increase in intracellular calcium. Application of the thiol-reducing agent dithiothreitol during the sustained phase of HPV reversed hypoxic vasoconstriction, whereas the superoxide scavenger nitroblue tetrazolium prevented further hypoxic pulmonary vasoconstriction during the sustained phase of $\mathrm{HPV}$, but did not reverse it [62].

As summarised in table 1, measurement of ROS has been performed by different methods, but no consensus regarding an up or downregulation could be achieved up to now. The lack of valid techniques for ROS measurement may be one reason for the uncertainty with regard to their role in HPV. Technical limitations of different fluorescent probes with regard to their lack of specificity and auto-oxidation [100] have been the major drawbacks in the past. In addition, artefacts due to a nonphysiological environment of isolated arteries and PASMC have to be considered. For example, pretone may influence ROS production by activation of stretchsensitive NADPH oxidase [101] and some investigators believe that healthy mitochondria do not release ROS under baseline conditions at all [102]. However, it is still curious why different groups have obtained different results with similar techniques. Apart from artefacts related to the ROS detection methodology and the experimental models employed (isolated lungs, vessels or cells), the kinetics and time-frame of the measurements (related to the kinetics of HPV) must also be taken into account as potential sources for discordant data. The question of the location of the ROS in particular must also be considered. Therefore, the apparently conflicting conclusions concerning ROS in HPV may be explained by the hypothesis that a local, subcellular and compartmentalised regulation of ROS triggers HPV. This may also be true for the intact organ where a clear majority of investigations demonstrate a decrease in ROS, measured with different methods, although evidence for increased ROS was obtained when some of the ROS-generating systems were blocked (table 1) [103]. Moreover, recent findings of enrichment of ion channels in membrane microdomains may also support the theory of compartimentalisation [104].

\section{THE OXYGEN SENSOR OF HPV}

To identify the triggering mechanism of HPV, two main assumptions have to be made: 1) the sensor has to be an oxygen consuming or binding protein/organelle with sensitivity also in the range of mild hypoxia; and 2) the sensor has to communicate with the PAMSC, the effector cell of HPV. This underscores the 
TABLE 1 Hypoxia induced changes of reactive oxygen species (ROS)

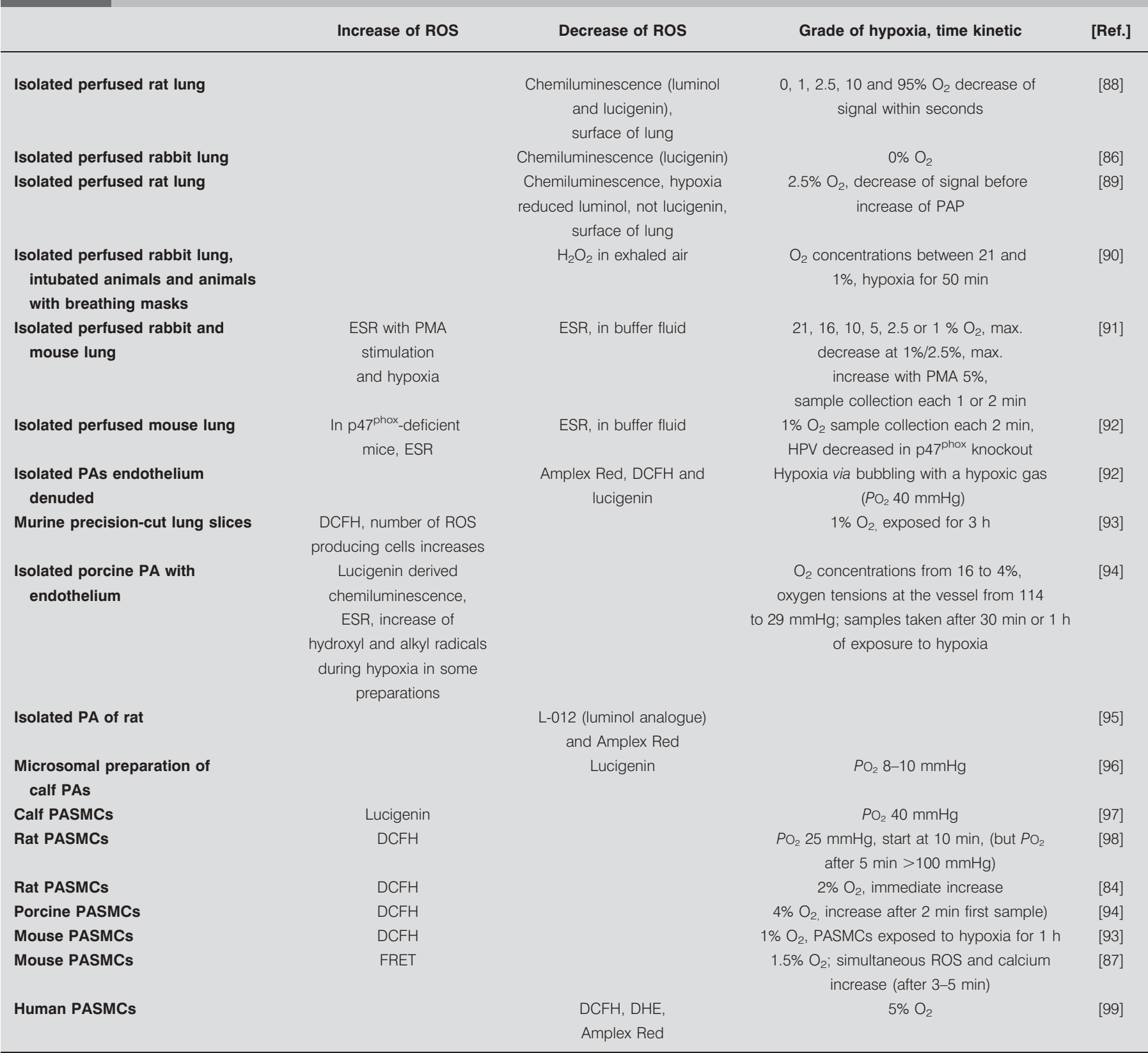

PA: pulmonary artery; PASMC: pulmonary artery smooth muscle cell; ESR: electron spin resonance; PMA: phorbol-12-myristate-13-acetate; DCFH: 2', 7'dichlorfluorescein-diacetate; FRET: fluorescence resonance energy transfer; DHE: dihydroethidium; PAP: pulmonary arterial pressure; max: maximum; HPV: hypoxic pulmonary vasoconstriction; $\mathrm{PO}_{2}$ : partial pressure of oxygen. $1 \mathrm{mmHg}=0.133 \mathrm{kPa}$.

problem of defining hypoxia. HPV in the isolated lung exhibits a sigmoidal stimulus-response relationship to varying degrees of alveolar hypoxia in a portion of investigations, with an onset at 50-70 mmHg (6.66-9.33 kPa) and half-maximal response at 30$50 \mathrm{mmHg}(3.99-6.66 \mathrm{kPa})$ [8]. For sustained hypoxia, lasting for 20-40 min, a biphasic stimulus-response relationship with a maximal vasoconstriction at an average $P_{\mathrm{O}_{2}}$ of $25 \mathrm{mmHg}$ $(3.33 \mathrm{kPa})$ and decreasing vasoconstriction [10] or even vasodilatation [105] at lower oxygen concentrations was demonstrated, but not all investigations reported biphasic kinetics of HPV.
Isolated cells were reported to contract in response to a $\mathrm{PO}_{2}$ of $25-50 \mathrm{mmHg}(3.33-6.66 \mathrm{kPa})[26,27]$, whereas studies with measurement of intracellular calcium were usually performed at $\mathrm{PO}_{2}$ levels $<30 \mathrm{mmHg}(3.99 \mathrm{kPa})[36,106,107]$. Integrating these data, it is clear that a sensor must exhibit sensitivity to at least $50 \mathrm{mmHg}(6.66 \mathrm{kPa})$ and below. Regardless of the debate on the dependence of HPV on priming factors, the primary oxygen sensor is obviously located in the PASMC as isolated PASMC contract in response to hypoxia and increase their intracellular $\mathrm{Ca}^{2+}$. 


\section{MITOCHONDRIA IN THE CELL}

The importance of mitochondria in HPV signalling pathways is undisputable, since their exact role has been the basis of debate for many years. Mitochondria are the main oxygen consuming cell organelles and the application of inhibitors has been used to elucidate the mechanism of HPV [84, 108-110].

Mitochondria may regulate or trigger HPV by hypoxic inhibition of complex IV, regulation of ROS metabolism or controlling calcium homeostasis in the cell. In regard to the general requirement of oxygen sensors in HPV, which is sensitivity to mild hypoxia, high oxygen affinity of the key enzyme in complex IV seemed to prevent a decrease of adenosine triphosphate (ATP) under conditions of mild hypoxia [111]. In line with this notion, no ATP depletion $[112,113]$ was evident in the whole lung during hypoxia, although this might be due to a shift from oxidative phosphorylation to glycolytic ATP production [114]. This mechanism is further supported by tissue-specific modulation of oxygen affinity of cytochrome c oxidase of complex IV, for example, by NO, CO or ROS, and may affect the adenosine monophosphate/ATP ratio to induce calcium release from intracellular stores via cyclic adenosine diphosphate ribose and not necessarily by ATP depletion [115]. In contrast to observations on acute HPV, there is evidence that oxidative ATP generation is impaired in isolated PAs during sustained HPV [116], in salt perfused PAs (even after 4 min [117]) and in intact lung during severe hypoxia $(<10 \mathrm{mmHg}(<1.33 \mathrm{kPa}))$ [118]. During sustained hypoxia the cellular energy state is balanced by an upregulation of glycolysis [112, 116, 119]. However, since exposure of PAs to prolonged hypoxia may cause ATP-sensitive potassium channels to open due to ATP depletion, the balance of energy state may be incompletely achieved [120]. This may explain the higher sensitivity of HPV to mitochondrial inhibition during prolonged hypoxia [103]. A hint at some potential inhibition of the mitochondrial respiratory chain during hypoxia is the high $\mathrm{NADH} /$ nicotinamide adenine dinulceotide (NAD) ratio during acute hypoxia (15-18 $\mathrm{mmHg}(1.99-2.39 \mathrm{kPa}))$ [119], but not the NADPH/NADP ratio (35-60 $\mathrm{mmHg}(4.66-7.99 \mathrm{kPa})$ ) [117] in isolated PAs. Although the redox state is an important determinant for the gating of redox-sensitive ion channels, no correlation with HPV in isolated PAs could be demonstrated during application of mitochondrial inhibitors [119]. Nevertheless the failure of inhibiting HPV by inhibition of complex IV with cyanide in some investigations (table 2) questioned the general importance of hypoxic inhibition of complex IV. For this reason, and the potentially "wrong" reaction range of complex IV, studies focused on an oxygen sensing mechanism via mitochondrial ROS production independent of complex IV. Again, different concepts with regard to ROS production have emerged. The ROS production by mitochondria has been suggested to be decreased or increased by direct measurement (table 1) and to originate from complex I, II or III of the respiratory chain [98, 110, 122]. The original redox hypothesis was proposed by WEIR and ARCHER [123] and ARCHER et al. [89] that assumed a decrease in the production of mitochondrial ROS, resulting in the inhibition of $\mathrm{K}_{\mathrm{v}}$ channels mediated by redox couples, such as GSH/GSSG and NADH/ NAD ratio. The inhibitors of complex I and III, respectively, decreased ROS, caused vasoconstriction during normoxia, and inhibited HPV in isolated lungs, PAs and PASMCs. At the same time they inhibited $\mathrm{K}_{\mathrm{v}}$ channels. Conversely, cyanide increased ROS, and also caused vasoconstriction during normoxia, but did not inhibit HPV [89, 92]. From these experiments, the conclusion was drawn that decreased ROS production of the mitochondrial respiratory chain upstream of complex IV is necessary for HPV. In contrast, WAYPA and coworkers [77, 84] suggested that an increase in ROS production during hypoxia triggers subsequent intracellular calcium release and thus HPV. Arguments of increased ROS from the semiubiquinone binding site in mitochondrial complex III are mainly related to rotenone (inhibition of complex I) and myxothiazol (inhibition of complex III proximal to the suggested superoxide production site) attenuating the hypoxia-induced increase in intracellular $\mathrm{Ca}^{2+}$ in PASMCs and HPV and myxothiazol inhibiting the hypoxic ROS production. In contrast, antimycin A (inhibition of complex III distal to the suggested superoxide production site), which is assumed to increase hypoxic ROS production, did not attenuate the hypoxia-induced $\mathrm{Ca}^{2+}$ increase and had no effect on HPV. In line with these observations, cyanide (inhibition of complex IV) did not inhibit HPV. Direct measurements with a new fluorescence resonance energy transfer method support the theory of ROS increase during HPV [87]. An elegant extension of the experiments is the application of succinate, which restores rotenone-inhibited effects by restoring function of complex III [119]. Effects of mitochondrial inhibitors are summarised in table 2, and provide arguments for both concepts, although generally their specificity should be considered carefully [109]. Both mechanisms could cause vasoconstricton by modulating ion channels and could be triggered or modulated by hypoxia. Generally, mitochondrial ROS can be increased by unspecific interference of oxygen with the mitochondrial membrane [124], increased time life of ubisemiquinone, e.g. by peripheral inhibition, electron backflow through complex II [93], mitochondrial calcium influx [125] or activation of mitochondrial potassium channels [126]. A decrease in the ROS level can be caused by a decreased $P_{\mathrm{O}_{2}}$, electron flux through respiratory chain, or membrane potential. Besides being a possible trigger organelle, mitochondria can be a modulator of HPV. In particular, calcium homeostasis of the cell is regulated by mitochondria, by calcium buffering [127-129] and regulating capacitative calcium entry [130].

\section{NADPH OXIDASE}

The NADPH oxidases are superoxide/producing multiprotein complexes consisting of the transmembrane superoxide producing subunits and cytosolic subunits. The classical leukocyte NADPH oxidase is composed of the transmembrane subunits gp91 phox (now also termed NOX2) and p22, which comprises of cytochrome b558, and the cytosolic subunits p47phox, p67phox and p40phox. Compared with the leukocytic NADPH oxidase, which is activated by an assembly of the cytosolic and the membrane-bound subunits, certain nonphagocytic NADPH oxidases that substitute gp91 (NOX2), e.g. by the newly identified isoforms NOX1 and NOX4 [131], constitutively produce low amounts of superoxide in the intracellular compartment, probably by assembly of NOX1 with subunit p47 homologue NOX-O1 [131, 132]. Activation by assembly can be induced by phosphorylation of the p47phox subunit and Rac GTPase, for example [133]. Such regulation of NADPH 
TABLE 2 Influence of mitochondrial inhibition on hypoxic pulmonary vasoconstriction (HPV) and normoxic vessel tone

\begin{tabular}{|c|c|c|c|c|c|}
\hline & ROS & Normoxic tone & HPV & Model & [Ref.] \\
\hline \multirow[t]{5}{*}{ Rotenone } & $\downarrow$ & $\uparrow$ & Inhibited & Whole lung and PASMCs & [89] \\
\hline & & $\uparrow$ & Inhibited, unspecifically & Isolated lung & [108] \\
\hline & $\downarrow$ & $\uparrow$ & & Vessel wall & [93] \\
\hline & & $\begin{array}{l}\text { No change with } \\
\text { inhibited NO }\end{array}$ & $\begin{array}{l}\text { Inhibited, specificity pronounced } \\
\text { under blocked NO }\end{array}$ & Isolated rabbit lung & [109] \\
\hline & & No change & Inhibited & PAs & [119] \\
\hline 3-NPA & $\begin{array}{l}\text { Prevents hypoxia } \\
\text { induced increase }\end{array}$ & $\uparrow$ & Inhibited & Intraacinar arteries & [121] \\
\hline \multirow[t]{5}{*}{ Antimycin A } & $\begin{array}{c}\downarrow \text { in normoxia and } \\
\text { hypoxia }\end{array}$ & $\uparrow$ & Inhibited & Whole lung & [89] \\
\hline & $\downarrow$ & $\uparrow$ & Inhibited & $\begin{array}{c}\text { PA and PASMCs opposite } \\
\text { in renal tissue }\end{array}$ & [92] \\
\hline & & $\uparrow$ & Inhibited, unspecifically & Isolated rat lung & [108] \\
\hline & & $\uparrow$ & $\begin{array}{l}\text { Inhibited unspecifically in high } \\
\text { concentrations, no change in low } \\
\text { concentrations }\end{array}$ & Buffer perfused lung & {$[84]$} \\
\hline & $\downarrow$ in normoxia and & $\uparrow$ & Pronounced vasodilation & PA & [121] \\
\hline \multirow{2}{*}{ Myxothiazol } & & No change & Inhibited & IPA & [119] \\
\hline & & $\begin{array}{l}\text { No change with } \\
\text { inhibited NO }\end{array}$ & $\begin{array}{l}\text { HPV inhibited unspecifically, } \\
\text { especially under preblocked NO }\end{array}$ & Isolated lung & [109] \\
\hline \multirow[t]{6}{*}{ Cyanide } & $\uparrow$ & $\begin{array}{c}\uparrow \text {, inhibited by } \\
\text { SOD }\end{array}$ & No change & Whole lung PASMCs & [89] \\
\hline & $\begin{array}{l}\text { No change during } \\
\text { hypoxia }\end{array}$ & & $\begin{array}{c}\text { Increased intracellular } \mathrm{Ca}^{2+} \\
\text { during hypoxia }\end{array}$ & PASMCs & {$[87]$} \\
\hline & & $\begin{array}{c}\uparrow, \text { inhibited by } \\
\text { ebselen and myxo- } \\
\text { thiazol }\end{array}$ & $\uparrow$ & Buffer perfused lung & [84] \\
\hline & & No change & $\begin{array}{l}\text { No effect on phase } 1 \text {, } \\
\text { potentiates phase } 2\end{array}$ & PAs & [119] \\
\hline & & $\uparrow$ & Inhibited, unspecifically & Isolated rat lung & [108] \\
\hline & & $\uparrow$ & Inhibited, especially phase 2 & Rabbit lung & [92] \\
\hline \multirow[t]{2}{*}{ Azide } & & $\uparrow$ & Inhibited, unspecifically & Isolated rat lung & [108] \\
\hline & No change & & Inhibited, unspecifically & PA & [121] \\
\hline
\end{tabular}

Vasoconstriction during normoxia when applying the inhibitor is usually smaller than HPV and of transient character. ROS: reactive oxygen specificity; 3-NPA: 3nitropropionic acid; HQNO: 2n-heptyl-4-hydroxyquinoline-N-oxide; SDH: succinate dehydrogenase; No: nitric oxide; SOD: superoxide dismutase; PASMC: pulmonary arterial smooth muscle cells; PA: pulmonary arteries; IPA: intrapulmonary arteries. $\downarrow$ : decrease; $\uparrow$ : increase. 


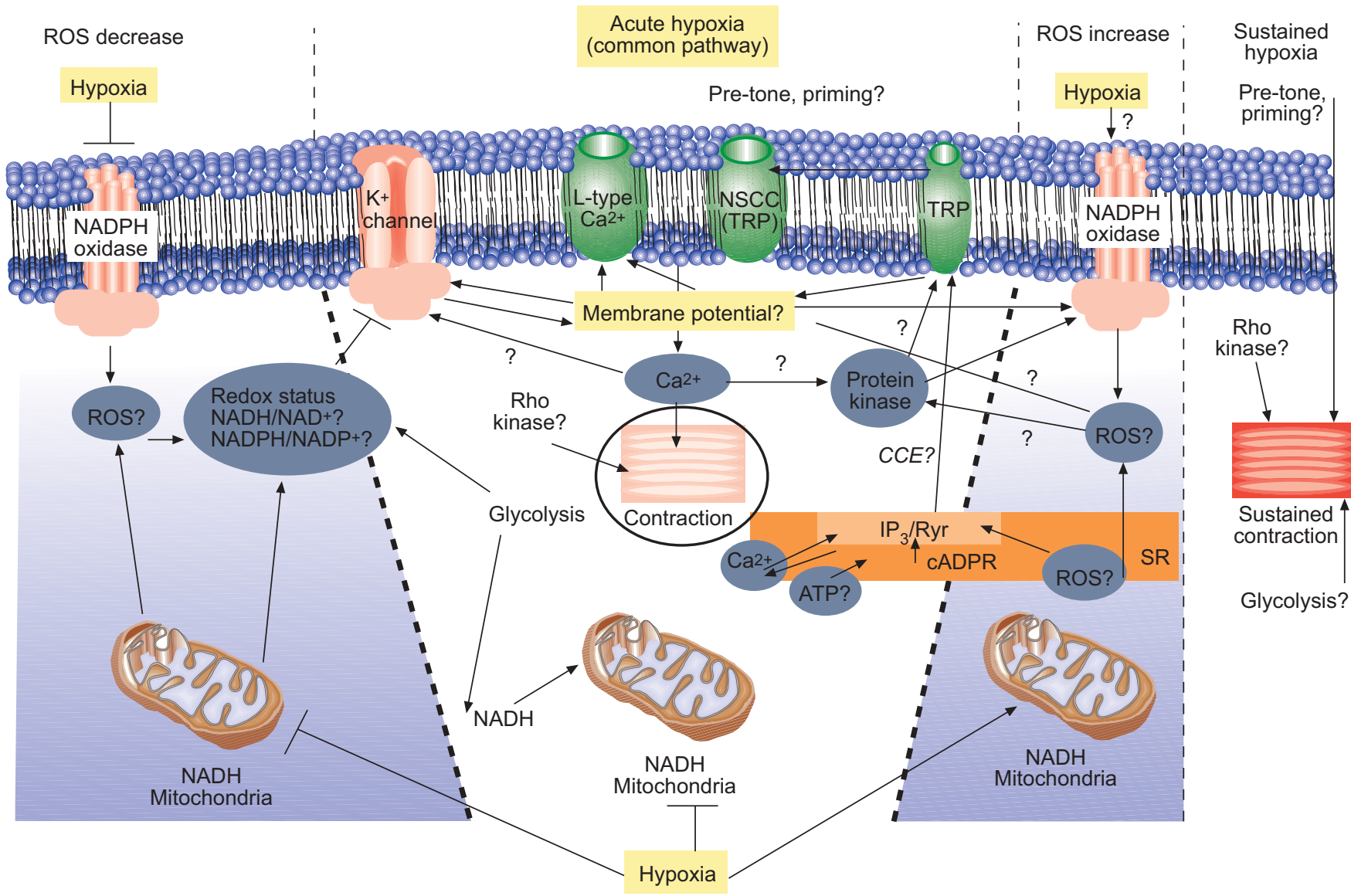

FIGURE 1. Pathways involved in hypoxic pulmonary vasoconstriction. Acute hypoxia results in an increase of intracellular calcium in pulmonary arterial smooth muscle cells and thus contraction. This increase in calcium is achieved by inflow of extracellular calcium through plasmalemnal calcium channels and release of intracellularly stored calcium. Hypoxic effects could be mediated or modulated by a decrease (left side) or increase (right side) of reactive oxygen species (ROS). NADPH: reduced nicotinamide adenine dinucleotide phosphate; NSCC: nonspecific cation channels; TRP: transient receptor potential; NADH: reduced nicotinamide adenine dinucleotide; NAD: nicotinamide adenine dinulceotide; NADP: nicotinamide adenine dinucleotide phosphate; CCE: capacitative calcium entry; ATP: adenosine triphosphate; IP: inositol triphosphate; cADPR: cyclic ADP-ribose; SR: sarcoplasmatic reticulum.

oxidase activity may involve phospholipase A2 and protein kinase C (PKC) [134, 135]. Classical NADPH oxidase activity depends on membrane potential in the physiological range and the NADPH concentration [136, 137]. In leukocytic cells, activation of NADPH oxidase leads to rapid depolarisation of the cell, because of outward movements of electrons [138, 139].

In vascular smooth muscle cells, NADPH-dependent ROS production occurs mainly intracellularly [131] and has been proposed to be the main ROS producing system compared with other cellular systems [140]. Leukocytic NADPH oxidase superoxide production was shown to be dependent on $\mathrm{PO}_{2}$, with a slow decrease of ROS release with decreasing $\mathrm{PO}_{2}$ and a sharp decline at an $\mathrm{O}_{2}$ concentration $<1 \%$ [141].

However, in isolated perfused lungs, intravascular NADPH oxidase dependent superoxide concentration increased during graded hypoxia peaking at $5 \% \mathrm{O}_{2}$, when NADPH oxidase was maximally stimulated with phorbol-12-myristate-13-acetate; however, under nonstimulated conditions superoxide release decreased with hypoxia. It was concluded that regulation of electron flux rather than oxygen may be the rate-limiting step in superoxide formation, from nonphagocytic NADPH oxidase [91].
Regarding its role in HPV, MARSHALL et al. [97] first described an $\mathrm{NAD}(\mathrm{P}) \mathrm{H}$ oxidase in PAs with an unusually low redox potential. Isolated PASMCs demonstrated an increase in superoxide production under hypoxic conditions, which was suggested to be derived from NADPH oxidase. Several studies showed inhibition of HPV by diphenyleneiodonium (DPI) $[142,143]$. However, DPI was proven to inhibit flavin adenine dinucleotide-dependent enzymes in general and thus also those of the mitochondrial chain $[144,145]$. To overcome this problem, different NADPH oxidase inhibitors were investigated as follows: apocynin, which, 1) interfered with vascular tone in general in isolated rabbit lung studies; and 2) 4-(2aminoethyl)benzenesulfonyl fluoride, which selectively inhibited HPV in isolated rabbit lungs [143]. Recently, cadmium sulphate, which is thought to be more specific than DPI, also showed inhibition of HPV in isolated rat PAs [146]. The current authors' investigations suggested an activation of a $\mathrm{NAD}(\mathrm{P}) \mathrm{H}$ oxidase during hypoxia, as all the blockers inhibited, but did not mimic HPV [147].

As an extension of these studies PKC, a possible activator of the NADPH oxidase, has been suggested to regulate HPV via 
NADPH oxidases [135] (although PKC may also affect HPV without interaction with an NADPH oxidase [73]), and a phospholipase $\mathrm{A}_{2}$ knockout mouse exhibited reduced HPV, which may also interfere with the NADPH oxidase pathway $[134,148]$. However, the NADPH oxidase concept of oxygen sensing then seemed to be rejected in study by ARCHER et al. [149], who demonstrated that gp91phox-deficent mice fully responded to acute hypoxia. Although this clearly excludes the role of the phagocytic NADPH oxidase type in HPV, the present authors recently demonstrated that mice deficient of the cytosolic NADPH oxidase subunit p47 had a $\sim 25 \%$ reduced acute, but unchanged sustained HPV [92]. This supports the concept that isoforms of the leukocytic NADPH oxidase may, at least in part, function as oxygen sensors in HPV.

\section{CONCLUSION: INTEGRATING MULTIPLE EFFECTS}

Although understanding the precise sequence and interdependence of events leading to HPV is still far away, a more detailed picture of the pathways involved is being created. Hypothetically, the findings summarised in this review may be integrated into a complex model (fig. 1). There are multiple components (L-type calcium channels, $\mathrm{K}_{\mathrm{v}}$ channels, NSCC (e.g. TRP channels) and Rho-kinase) involved that could be activated sequentially or in parallel during HPV and lead to an intracellular calcium increase and/or calcium sensitisation and thus HPV. The contribution of these mechanisms is generally accepted; however, there are opposing theories regarding the contribution of ROS. One theory favours an increase of ROS for the signal transduction underlying HPV and others emphasise a decrease of ROS.

Assuming an increase of ROS underlying the signal transduction of HPV, it was suggested that hypoxia: 1) interferes with mitochondrial complex I/III or inhibits complex IV, above the range of changing the cellular energy status, to increase ROS; or 2) that an activation of NADPH oxidases by a yet unknown mechanism may lead to an increase of ROS.

A decrease of ROS has been attributed to a decreased mitochondrial ROS release (from complex I and III). This decrease then may lead to a more reduced cellular redox status, which inhibits $\mathrm{K}_{\mathrm{v}}$ channels. Inhibition of $\mathrm{K}_{\mathrm{v}}$ channels results in membrane depolarisation and activation of L-type calcium channels $[89,110,150,151]$. Moreover, $\mathrm{K}_{\mathrm{v}}$ channels have been shown to be inhibited by antioxidants [45]. However, even the importance of ROS itself was questioned [152] and cADP-ribose, for example, has been suggested as another signalling molecule [115]. Exact $\mathrm{PO}_{2}$ dependence and localisation of subcellular ROS production may resolve the currently contradictory findings with regard to the contribution of ROS to HPV.

Interfering effects between the different pathways suggested to contribute to HPV may further complicate the issue. For example, NADPH oxidases can be activated by protein kinases, which have been shown to be essential in HPV [73], and mitochondrial ROS production can be influenced by cellular $\mathrm{Ca}^{2+}$ levels [153]. Moreover, mitochondria play an important role in regulation of cellular $\mathrm{Ca}^{2+}$ homeostasis [129] and capacitative $\mathrm{Ca}^{2+}$ entry [154], which has been shown to be activated in HPV.
Thus, although a portion of the pathways essential for hypoxia pulmonary vasoconstriction have been identified there are still plenty of open questions to solve before a complete picture about the oxygen sensing and signal transduction mechanisms of this important physiological response can be achieved.

\section{REFERENCES}

1 Marshall BE, Marshall C, Benumof J, Saidman LJ. Hypoxic pulmonary vasoconstriction in dogs: effects of lung segment size and oxygen tension. J Appl Physiol 1981; 51: 1543-1551.

2 Orchard CH, Sanchez de Leon R, Sykes MK. The relationship between hypoxic pulmonary vasoconstriction and arterial oxygen tension in the intact dog. J Physiol 1983; 338: 61-74.

3 Naeije R, Brimioulle S. Physiology in medicine: importance of hypoxic pulmonary vasoconstriction in maintaining arterial oxygenation during acute respiratory failure. Crit Care 2001; 5: 67-71.

4 Carter EP, Hartsfield CL, Miyazono M, Jakkula M, Morris KG Jr, McMurtry IF. Regulation of heme oxygenase-1 by nitric oxide during hepatopulmonary syndrome. Am J Physiol Lung Cell Mol Physiol 2002; 283: 346-353.

5 Marshall BE. Hypoxic pulmonary vasoconstriction. Acta Anaesthesiol Scand Suppl 1990; 94: 37-41.

6 Weir EK. Does normoxic pulmonary vasodilatation rather than hypoxic vasoconstriction account for the pulmonary pressor response to hypoxia? Lancet 1978; 1 : 476-477.

7 Weissmann N, Akkayagil E, Quanz K, et al. Basic features of hypoxic pulmonary vasoconstriction in mice. Respir Physiol Neurobiol 2004; 139: 191-202.

8 Weissmann N, Grimminger F, Walmrath D, Seeger W. Hypoxic vasoconstriction in buffer-perfused rabbit lungs. Respir Physiol 1995; 100: 159-169.

9 Lindgren L, Marshall C, Marshall BE. Hypoxic pulmonary vasoconstriction in isolated rat lungs perfused with perfluorocarbon emulsion. Acta Physiol Scand 1985; 123: 335-338.

10 Peake MD, Harabin AL, Brennan NJ, Sylvester JT. Steady-state vascular responses to graded hypoxia in isolated lungs of five species. J Appl Physiol 1981; 51: 1214-1219.

11 Skovgaard N, Abe AS, Andrade DV, Wang T. Hypoxic pulmonary vasoconstriction in reptiles: a comparative study of four species with different lung structures and pulmonary blood pressures. Am J Physiol Regul Integr Comp Physiol 2005; 289: 1280-1288.

12 Olson KR, Russell MJ, Forster ME. Hypoxic vasoconstriction of cyclostome systemic vessels: the antecedent of hypoxic pulmonary vasoconstriction? Am J Physiol Regul Integr Comp Physiol 2001; 280: 198-206.

13 Plumier L. La circulation pulmonaire chez le chien [Pulmonary circulation in the dog]. Arch Int Physiol 1904; 1: 176-213.

14 Bradford JR, Dean HP. The pulmonary circulation. J Physiol (Lond) 1894; 16: 34-96. 
15 Von Euler US, Liljestrand G. Observations on the pulmonary arterial blood pressure in the cat. Acta Physiol Scand 1946; 12: 301-320.

16 Motley HL, Cournand A, Werko L, Himmelstein A, Dresdale D. The influence of short periods of induced acute anoxia upon pulmonary arterial pressure in man. Am J Physiol 1947; 150: 315-320.

17 Sylvester JT, Gottlieb JE, Rock P, Wetzel RC. Acute hypoxic responses. In: Bergofsky EF, ed. Abnormal Pulmonary Circulation. New York, Churchill-Livingstone, 1986; pp. 127-165.

18 Stroud RC, Rahn $\mathrm{H}$. Effect of $\mathrm{O}_{2}$ and $\mathrm{CO}_{2}$ tensions upon the resistance of pulmonary blood vessels. Am J Physiol 1953; 172: 211-220.

19 Fishman AP. Hypoxia on the pulmonary circulation. How and where it acts. Circ Res 1976; 38: 221-231.

20 Cutaia M, Rounds S. Hypoxic pulmonary vasoconstriction. Physiologic significance, mechanism, and clinical relevance. Chest 1990; 97: 706-718.

21 Davis MJ, Joyner WL, Gilmore JP. Microvascular pressure distribution and responses of pulmonary allografts and cheek pouch arterioles in the hamster to oxygen. Circ Res 1981; 49: 125-132.

22 Hillier SC, Graham JA, Hanger CC, Godbey PS, Glenny RW, Wagner WW Jr. Hypoxic vasoconstriction in pulmonary arterioles and venules. J Appl Physiol 1997; 82: 1084-1090.

23 Staub NC. Site of hypoxic pulmonary vasoconstriction. Chest 1985; 88: Suppl. 4, S240-S245.

24 Kato M, Staub NC. Response of small pulmonary arteries to unilobar hypoxia and hypercapnia. Circ Res 1966; 19: 426-440.

25 Dawson CA, Grimm DJ, Linehan JH. Influence of hypoxia on the longitudinal distribution of pulmonary vascular resistance. J Appl Physiol 1978; 44: 493-498.

26 Murray TR, Chen L, Marshall BE, Macarak EJ. Hypoxic contraction of cultured pulmonary vascular smooth muscle cells. Am J Respir Cell Mol Biol 1990; 3: 457-465.

27 Madden JA, Vadula MS, Kurup VP. Effects of hypoxia and other vasoactive agents on pulmonary and cerebral artery smooth muscle cells. Am J Physiol 1992; 263: 384-393.

28 Liu Q, Sham JS, Shimoda LA, Sylvester JT. Hypoxic constriction of porcine distal pulmonary arteries: endothelium and endothelin dependence. Am J Physiol Lung Cell Mol Physiol 2001; 280: 856-865.

29 Aaronson PI, Robertson TP, Ward JP. Endotheliumderived mediators and hypoxic pulmonary vasoconstriction. Respir Physiol Neurobiol 2002; 132: 107-120.

30 Weir EK, Olschewski A. Role of ion channels in acute and chronic responses of the pulmonary vasculature to hypoxia. Cardiovasc Res 2006; 71: 630-641.

31 Harder DR, Madden JA, Dawson C. Hypoxic induction of $\mathrm{Ca}^{2+}$-dependent action potentials in small pulmonary arteries of the cat. J Appl Physiol 1985; 59: 1389-1393.

32 Savineau JP, Gonzalez de la Fuente P, Marthan R. Cellular mechanisms of hypoxia-induced contraction in human and rat pulmonary arteries. Respir Physiol 1995; 99: 191-198.

33 Ohe M, Ogata M, Shirato K, Takishima T. Effects of verapamil and BAY K 8644 on the hypoxic contraction of the isolated human pulmonary artery. Tohoku J Exp Med 1989; 157: 81-82.

34 Tucker A, McMurtry IF, Grover RF, Reeves JT. Attenuation of hypoxic pulmonary vasoconstriction by verapamil in intact dogs. Proc Soc Exp Biol Med 1976; 151: 611-614.

35 Weigand L, Foxson J, Wang J, Shimoda LA, Sylvester JT. Inhibition of hypoxic pulmonary vasoconstriction by antagonists of store-operated $\mathrm{Ca}^{2+}$ and nonselective cation channels. Am J Physiol Lung Cell Mol Physiol 2005; 289: L5-L13.

36 Wang J, Shimoda LA, Weigand L, Wang W, Sun D, Sylvester JT. Acute hypoxia increases intracellular $\left[\mathrm{Ca}^{2+}\right]$ in pulmonary arterial smooth muscle by enhancing capacitative $\mathrm{Ca}^{2+}$ entry. Am J Physiol Lung Cell Mol Physiol 2005; 288: L1059-L1069.

37 Ward JP, Robertson TP, Aaronson PI. Capacitative calcium entry: a central role in hypoxic pulmonary vasoconstriction? Am J Physiol Lung Cell Mol Physiol 2005; 289: 2-4.

38 Yuan XJ, Goldman WF, Tod ML, Rubin LJ, Blaustein MP. Hypoxia reduces potassium currents in cultured rat pulmonary but not mesenteric arterial myocytes. Am J Physiol 1993; 264: 116-123.

39 Post JM, Hume JR, Archer SL, Weir EK. Direct role for potassium channel inhibition in hypoxic pulmonary vasoconstriction. Am J Physiol 1992; 262: 882-890.

40 Hasunuma K, Rodman DM, McMurtry IF. Effects of K+ channel blockers on vascular tone in the perfused rat lung. Am Rev Respir Dis 1991; 144: 884-887.

41 Patel AJ, Lazdunski M, Honore E. Kv2.1/Kv9.3, a novel ATP-dependent delayed-rectifier $\mathrm{K}+$ channel in oxygensensitive pulmonary artery myocytes. Embo J 1997; 16: 6615-6625.

42 Hulme JT, Coppock EA, Felipe A, Martens JR, Tamkun MM. Oxygen sensitivity of cloned voltage-gated $\mathrm{K}(+)$ channels expressed in the pulmonary vasculature. Circ Res 1999; 85: 489-497.

43 Archer SL, Souil E, Dinh-Xuan AT, et al. Molecular identification of the role of voltage-gated $\mathrm{K}+$ channels, $\mathrm{Kv} 1.5$ and $\mathrm{Kv} 2.1$, in hypoxic pulmonary vasoconstriction and control of resting membrane potential in rat pulmonary artery myocytes. J Clin Invest 1998; 101: 2319-2330

44 Archer SL, London B, Hampl V, et al. Impairment of hypoxic pulmonary vasoconstriction in mice lacking the voltage-gated potassium channel Kv1.5. FASEB J 2001; 15: 1801-1803.

45 Reeve HL, Weir EK, Nelson DP, Peterson DA, Archer SL. Opposing effects of oxidants and antioxidants on $\mathrm{K}+$ channel activity and tone in rat vascular tissue. Exp Physiol 1995; 80: 825-834.

46 Weir EK, Hong Z, Porter VA, Reeve HL. Redox signalling in oxygen sensing by vessels. Respir Physiol Neurobiol 2002; 132: 121-130.

47 Park MK, Bae YM, Lee SH, Ho WK, Earm YE. Modulation of voltage-dependent $\mathrm{K}+$ channel by redox potential in pulmonary and ear arterial smooth muscle cells of the rabbit. Pflugers Arch 1997; 434: 764-771.

48 Olschewski A, Hong Z, Peterson DA, Nelson DP, Porter VA, Weir EK. Opposite effects of redox status on membrane potential, cytosolic calcium, and tone in 
pulmonary arteries and ductus arteriosus. Am I Physiol Lung Cell Mol Physiol 2004; 286: 15-22.

49 Yuan XJ, Tod ML, Rubin LJ, Blaustein MP. Deoxyglucose and reduced glutathione mimic effects of hypoxia on $\mathrm{K}+$ and $\mathrm{Ca}^{2+}$ conductances in pulmonary artery cells. Am J Physiol 1994; 267: L52-L63.

50 Lin MJ, Leung GP, Zhang WM, et al. Chronic hypoxiainduced upregulation of store-operated and receptoroperated $\mathrm{Ca}^{2+}$ channels in pulmonary arterial smooth muscle cells: a novel mechanism of hypoxic pulmonary hypertension. Circ Res 2004; 95: 496-505.

$51 \mathrm{Yu}$ Y, Fantozzi I, Remillard CV, et al. Enhanced expression of transient receptor potential channels in idiopathic pulmonary arterial hypertension. Proc Natl Acad Sci USA 2004; 101: 13861-13866.

$52 \mathrm{Ng}$ LC, Wilson SM, Hume JR. Mobilization of sarcoplasmic reticulum stores by hypoxia leads to consequent activation of capacitative $\mathrm{Ca} 2+$ entry in isolated canine pulmonary arterial smooth muscle cells. J Physiol 2005; 563: 409-419.

53 Snetkov VA, Aaronson PI, Ward JP, Knock GA, Robertson TP. Capacitative calcium entry as a pulmonary specific vasoconstrictor mechanism in small muscular arteries of the rat. Br J Pharmacol 2003; 140: 97-106.

54 Weissmann N, Dietrich A, Fuchs B, et al. Classical transient receptor potential channel 6 (TRPC6) is essential for hypoxic pulmonary vasoconstriction and alveolar gas exchange. Proc Natl Acad Sci USA 2006; 103: 19093-19098.

55 Post JM, Gelband $\mathrm{CH}$, Hume JR. [ $\left.\mathrm{Ca}^{2+}\right]$ i inhibition of $\mathrm{K}+$ channels in canine pulmonary artery. Novel mechanism for hypoxia-induced membrane depolarization. Circ Res 1995; 77: 131-139.

56 Gelband $\mathrm{CH}$, Gelband $\mathrm{H}$. $\mathrm{Ca}^{2+}$ release from intracellular stores is an initial step in hypoxic pulmonary vasoconstriction of rat pulmonary artery resistance vessels. Circulation 1997; 96: 3647-3654.

57 Morio Y, McMurtry IF. $\mathrm{Ca}^{2+}$ release from ryanodinesensitive store contributes to mechanism of hypoxic vasoconstriction in rat lungs. J Appl Physiol 2002; 92: 527-534.

58 Jabr RI, Toland H, Gelband CH, Wang XX, Hume JR. Prominent role of intracellular $\mathrm{Ca}^{2+}$ release in hypoxic vasoconstriction of canine pulmonary artery. $\mathrm{Br} J$ Pharmacol 1997; 122: 21-30.

59 Kang TM, Park MK, Uhm DY. Characterization of hypoxia-induced $\left[\mathrm{Ca}^{2+}\right]$ i rise in rabbit pulmonary arterial smooth muscle cells. Life Sci 2002; 70: 2321-2333.

60 Dipp M, Nye PC, Evans AM. Hypoxic release of calcium from the sarcoplasmic reticulum of pulmonary artery smooth muscle. Am J Physiol Lung Cell Mol Physiol 2001; 281: 318-325.

61 Zable AC, Favero TG, Abramson JJ. Glutathione modulates ryanodine receptor from skeletal muscle sarcoplasmic reticulum. Evidence for redox regulation of the $\mathrm{Ca}^{2+}$ release mechanism. J Biol Chem 1997; 272: 7069-7077.

62 Du W, Frazier M, McMahon TJ, Eu JP. Redox activation of intracellular calcium release channels (ryanodine receptors) in the sustained phase of hypoxia-induced pulmonary vasoconstriction. Chest 2005; 128: Suppl. 6, S556-S558.
63 Favero TG, Zable AC, Abramson JJ. Hydrogen peroxide stimulates the $\mathrm{Ca} 2+$ release channel from skeletal muscle sarcoplasmic reticulum. J Biol Chem 1995; 270: 25557-25563.

64 Wilson HL, Dipp M, Thomas JM, Lad C, Galione A, Evans AM. Adp-ribosyl cyclase and cyclic ADP-ribose hydrolase act as a redox sensor. a primary role for cyclic ADP-ribose in hypoxic pulmonary vasoconstriction. J Biol Chem 2001; 276: 11180-11188.

65 Kaplin AI, Snyder SH, Linden DJ. Reduced nicotinamide adenine dinucleotide-selective stimulation of inositol 1,4,5-trisphosphate receptors mediates hypoxic mobilization of calcium. J Neurosci 1996; 16: 2002-2011.

66 Robertson TP, Dipp M, Ward JP, Aaronson PI, Evans AM. Inhibition of sustained hypoxic vasoconstriction by $\mathrm{Y}$ 27632 in isolated intrapulmonary arteries and perfused lung of the rat. Br J Pharmacol 2000; 131: 5-9.

67 Wang Z, Lanner MC, Jin N, Swartz D, Li L, Rhoades RA. Hypoxia inhibits myosin phosphatase in pulmonary arterial smooth muscle cells: role of Rho-kinase. Am J Respir Cell Mol Biol 2003; 29: 465-471.

68 Wojciak-Stothard B, Tsang LY, Paleolog E, Hall SM, Haworth SG. Rac1 and RhoA as regulators of endothelial phenotype and barrier function in hypoxia-induced neonatal pulmonary hypertension. Am J Physiol Lung Cell Mol Physiol 2006; 290: L1173-L1182.

69 Robertson TP. Point: release of an endothelium-derived vasoconstrictor and RhoA/Rho kinase-mediated calcium sensitization of smooth muscle cell contraction are/are not the main effectors for full and sustained hypoxic pulmonary vasoconstriction. J Appl Physiol 2007; 102: 2071-2072.

70 Bennie RE, Packer CS, Powell DR, Jin N, Rhoades RA. Biphasic contractile response of pulmonary artery to hypoxia. Am J Physiol 1991; 261: 156-163.

71 Marshall C, Marshall BE. Hypoxic pulmonary vasoconstriction is not endothelium dependent. Proc Soc Exp Biol Med 1992; 201: 267-270.

72 Leach RM, Robertson TP, Twort CH, Ward JP. Hypoxic vasoconstriction in rat pulmonary and mesenteric arteries. Am J Physiol 1994; 266: 223-231.

73 Ward JP, Knock GA, Snetkov VA, Aaronson PI. Protein kinases in vascular smooth muscle tone-role in the pulmonary vasculature and hypoxic pulmonary vasoconstriction. Pharmacol Ther 2004; 104: 207-231.

74 Wolin MS. Interactions of oxidants with vascular signalling systems. Arterioscler Thromb Vasc Biol 2000; 20: 1430-1442.

75 Sylvester JT. Hypoxic pulmonary vasoconstriction: a radical view. Circ Res 2001; 88: 1228-1230.

76 Sham JS. Hypoxic pulmonary vasoconstriction: ups and downs of reactive oxygen species. Circ Res 2002; 91: 649-651.

77 Waypa GB, Schumacker PT. Hypoxic pulmonary vasoconstriction: redox events in oxygen sensing. J Appl Physiol 2005; 98: 404-414.

78 Moudgil R, Michelakis ED, Archer SL. Hypoxic pulmonary vasoconstriction. J Appl Physiol 2005; 98: 390-403.

79 Ward JP. Point: hypoxic pulmonary vasoconstriction is mediated by increased production of reactive oxygen species. J Appl Physiol 2006; 101: 993-995.

80 Wilhelm J, Herget J. Role of ion fluxes in hydrogen peroxide pulmonary vasoconstriction. Physiol Res 1995; 44: $31-37$. 
81 Sheehan DW, Giese EC, Gugino SF, Russell JA. Characterization and mechanisms of $\mathrm{H}_{2} \mathrm{O}_{2}$-induced contractions of pulmonary arteries. Am J Physiol 1993; 264: H1542-H1547.

82 Jones RD, Thompson JS, Morice AH. The effect of hydrogen peroxide on hypoxia, prostaglandin F2 alpha and potassium chloride induced contractions in isolated rat pulmonary arteries. Pulm Pharmacol Ther 1997; 10: 37-42.

83 Weir EK, Eaton JW, Chesler E. Redox status and pulmonary vascular reactivity. Chest 1985; 88: Suppl. 4, S249-S52.

84 Waypa GB, Chandel NS, Schumacker PT. Model for hypoxic pulmonary vasoconstriction involving mitochondrial oxygen sensing. Circ Res 2001; 88: 1259-1266.

85 Weissmann N, Grimminger F, Voswinckel R, Conzen J, Seeger W. Nitro blue tetrazolium inhibits but does not mimic hypoxic vasoconstriction in isolated rabbit lungs. Am J Physiol 1998; 274: 721-727.

86 Paky A, Michael JR, Burke-Wolin TM, Wolin MS, Gurtner GH. Endogenous production of superoxide by rabbit lungs: effects of hypoxia or metabolic inhibitors. $J$ Appl Physiol 1993; 74: 2868-2874.

87 Waypa GB, Guzy R, Mungai PT, et al. Increases in mitochondrial reactive oxygen species trigger hypoxiainduced calcium responses in pulmonary artery smooth muscle cells. Circ Res 2006; 99: 970-978.

88 Archer SL, Nelson DP, Weir EK. Simultaneous measurement of $\mathrm{O}_{2}$ radicals and pulmonary vascular reactivity in rat lung. J Appl Physiol 1989; 67: 1903-1911.

89 Archer SL, Huang J, Henry T, Peterson D, Weir EK. A redox-based $\mathrm{O}_{2}$ sensor in rat pulmonary vasculature. Circ Res 1993; 73: 1100-1112.

90 Weissmann N, Vogels H, Schermuly RT, et al. Measurement of exhaled hydrogen peroxide from rabbit lungs. Biol Chem 2004; 385: 259-264.

91 Weissmann N, Kuzkaya N, Fuchs B, et al. Detection of reactive oxygen species in isolated, perfused lungs by electron spin resonance spectroscopy. Respir Res 2005; 6: 86.

92 Michelakis ED, Hampl V, Nsair A, et al. Diversity in mitochondrial function explains differences in vascular oxygen sensing. Circ Res 2002; 90: 1307-1315.

93 Paddenberg R, Ishaq B, Goldenberg A, et al. Essential role of complex II of the respiratory chain in hypoxia-induced ROS generation in the pulmonary vasculature. Am J Physiol Lung Cell Mol Physiol 2003; 284: 710-719.

94 Liu JQ, Sham JS, Shimoda LA, Kuppusamy P, Sylvester JT. Hypoxic constriction and reactive oxygen species in porcine distal pulmonary arteries. Am J Physiol Lung Cell Mol Physiol 2003; 285: 322-333.

95 Bonnet S, Michelakis ED, Porter CJ, et al. An abnormal mitochondrial-hypoxia inducible factor-1alpha-Kv channel pathway disrupts oxygen sensing and triggers pulmonary arterial hypertension in fawn hooded rats: similarities to human pulmonary arterial hypertension. Circulation 2006; 113: 2630-2641.

96 Mohazzab KM, Wolin MS. Properties of a superoxide anion-generating microsomal NADH oxidoreductase, a potential pulmonary artery $\mathrm{PO}_{2}$ sensor. Am J Physiol 1994; 267: 823-831.
97 Marshall C, Mamary AJ, Verhoeven AJ, Marshall BE. Pulmonary artery NADPH-oxidase is activated in hypoxic pulmonary vasoconstriction. Am J Respir Cell Mol Biol 1996; 15: 633-644.

98 Killilea DW, Hester R, Balczon R, Babal P, Gillespie MN. Free radical production in hypoxic pulmonary artery smooth muscle cells. Am J Physiol Lung Cell Mol Physiol 2000; 279: 408-412.

99 Mehta JP, Li CJ, Guardiola J, Cabrera JA, Weir KE, Eaton JW. Generation of oxidants by hypoxic human pulmonary and coronary smooth muscle cells. Chest 2008; 133: 1410-1414.

100 Archer S, Michelakis E. The mechanism(s) of hypoxic pulmonary vasoconstriction: potassium channels, redox $\mathrm{O}_{2}$ sensors, and controversies. News Physiol Sci 2002; 17: 131-137.

101 Oeckler RA, Kaminski PM, Wolin MS. Stretch enhances contraction of bovine coronary arteries via an $\mathrm{NAD}(\mathrm{P}) \mathrm{H}$ oxidase-mediated activation of the extracellular signalregulated kinase mitogen-activated protein kinase cascade. Circ Res 2003; 92: 23-31.

102 Staniek K, Nohl H. Are mitochondria a permanent source of reactive oxygen species? Biochim Biophys Acta 2000; 1460: 268-275.

103 Weissmann N, Zeller S, Schafer RU, et al. Impact of mitochondria and NADPH oxidases on acute and sustained hypoxic pulmonary vasoconstriction. Am J Respir Cell Mol Biol 2006; 34: 505-513.

104 Murray F, Insel PA, Yuan JX. Role of $\mathrm{O}_{2}$-sensitive $\mathrm{K}^{+}$and $\mathrm{Ca}^{2+}$ channels in the regulation of the pulmonary circulation: potential role of caveolae and implications for high altitude pulmonary edema. Respir Physiol Neurobiol 2006; 151: 192-208.

105 Sylvester JT, Harabin AL, Peake MD, Frank RS. Vasodilator and constrictor responses to hypoxia in isolated pig lungs. J Appl Physiol 1980; 49: 820-825.

106 Salvaterra CG, Goldman WF. Acute hypoxia increases cytosolic calcium in cultured pulmonary arterial myocytes. Am J Physiol 1993; 264: 323-328.

107 Waypa GB, Marks JD, Mack MM, Boriboun C, Mungai PT, Schumacker PT. Mitochondrial reactive oxygen species trigger calcium increases during hypoxia in pulmonary arterial myocytes. Circ Res 2002; 91: 719-726.

108 Rounds S, McMurtry IF. Inhibitors of oxidative ATP production cause transient vasoconstriction and block subsequent pressor responses in rat lungs. Circ Res 1981; 48: 393-400.

109 Weissmann N, Ebert N, Ahrens M, et al. Effects of mitochondrial inhibitors and uncouplers on hypoxic vasoconstriction in rabbit lungs. Am J Respir Cell Mol Biol 2003; 29: 721-732.

110 Michelakis ED, Thebaud B, Weir EK, Archer SL. Hypoxic pulmonary vasoconstriction: redox regulation of $\mathrm{O}_{2^{-}}$ sensitive $\mathrm{K}+$ channels by a mitochondrial $\mathrm{O}_{2}$-sensor in resistance artery smooth muscle cells. J Mol Cell Cardiol 2004; 37: 1119-1136.

111 Bell EL, Emerling BM, Chandel NS. Mitochondrial regulation of oxygen sensing. Mitochondrion 2005; 5: 322-332.

112 Buescher PC, Pearse DB, Pillai RP, Litt MC, Mitchell MC, Sylvester JT. Energy state and vasomotor tone in hypoxic pig lungs. J Appl Physiol 1991; 70: 1874-1881. 
113 Fisher $\mathrm{AB}$, Dodia C. Lung as a model for evaluation of critical intracellular $\mathrm{PO}_{2}$ and PCO. Am J Physiol 1981; 241: E47-E50.

114 Leach RM, Hill HS, Snetkov VA, Ward JP. Hypoxia, energy state and pulmonary vasomotor tone. Respir Physiol Neurobiol 2002; 132: 55-67.

115 Evans AM, Mustard KJ, Wyatt CN, et al. Does AMPactivated protein kinase couple inhibition of mitochondrial oxidative phosphorylation by hypoxia to calcium signaling in $\mathrm{O}_{2}$-sensing cells? J Biol Chem 2005; 280: 41504-41511.

116 Leach RM, Sheehan DW, Chacko VP, Sylvester JT. Energy state, $\mathrm{pH}$, and vasomotor tone during hypoxia in precontracted pulmonary and femoral arteries. Am J Physiol Lung Cell Mol Physiol 2000; 278: 294-304.

117 Shigemori K, Ishizaki T, Matsukawa S, Sakai A, Nakai T, Miyabo S. Adenine nucleotides via activation of ATPsensitive $\mathrm{K}+$ channels modulate hypoxic response in rat pulmonary artery. Am J Physiol 1996; 270: 803-809.

118 Wiener CM, Dunn A, Sylvester JT. ATP-dependent K+ channels modulate vasoconstrictor responses to severe hypoxia in isolated ferret lungs. J Clin Invest 1991; 88: 500-504.

119 Leach RM, Hill HM, Snetkov VA, Robertson TP, Ward JP. Divergent roles of glycolysis and the mitochondrial electron transport chain in hypoxic pulmonary vasoconstriction of the rat: identity of the hypoxic sensor. J Physiol 2001; 536: 211-224.

120 Wanstall JC, O’Brien E. In vitro hypoxia on rat pulmonary artery: effects on contractions to spasmogens and role of KATP channels. Eur J Pharmacol 1996; 303: 71-78.

121 Paddenberg R, Konig P, Faulhammer P, Goldenberg A, Pfeil U, Kummer W. Hypoxic vasoconstriction of partial muscular intra-acinar pulmonary arteries in murine precision cut lung slices. Respir Res 2006; 7: 93.

122 Guzy RD, Hoyos B, Robin E, et al. Mitochondrial complex III is required for hypoxia-induced ROS production and cellular oxygen sensing. Cell Metab 2005; 1: 401-408.

123 Weir EK, Archer SL. The mechanism of acute hypoxic pulmonary vasoconstriction: the tale of two channels. FASEB J 1995; 9: 183-189.

124 Guzy RD, Schumacker PT. Oxygen sensing by mitochondria at complex III: the paradox of increased reactive oxygen species during hypoxia. Exp Physiol 2006; 91: 807819.

125 Brookes PS, Yoon Y, Robotham JL, Anders MW, Sheu SS. Calcium, ATP, and ROS: a mitochondrial love-hate triangle. Am J Physiol Cell Physiol 2004; 287: 817-833.

126 Andrukhiv A, Costa AD, West IC, Garlid KD. Opening mitoKATP increases superoxide generation from complex I of the electron transport chain. Am J Physiol Heart Circ Physiol 2006; 291: H2067-H2074.

127 Wang Q, Wang YX, Yu M, Kotlikoff MI. Ca ${ }^{2+}$-activated $\mathrm{Cl}^{-}$currents are activated by metabolic inhibition in rat pulmonary artery smooth muscle cells. Am J Physiol 1997; 273: 520-530.

128 Drummond RM, Tuft RA. Release of $\mathrm{Ca}^{2+}$ from the sarcoplasmic reticulum increases mitochondrial $\left[\mathrm{Ca}^{2+}\right]$ in rat pulmonary artery smooth muscle cells. J Physiol 1999; 516: 139-147.
129 Duchen MR. Contributions of mitochondria to animal physiology: from homeostatic sensor to calcium signalling and cell death. J Physiol 1999; 516: 1-17.

130 Kang TM, Park MK, Uhm DY. Effects of hypoxia and mitochondrial inhibition on the capacitative calcium entry in rabbit pulmonary arterial smooth muscle cells. Life Sci 2003; 72: 1467-1479.

131 Lassegue B, Clempus RE. Vascular NAD $(\mathrm{P}) \mathrm{H}$ oxidases: specific features, expression, and regulation. Am J Physiol Regul Integr Comp Physiol 2003; 285: 277-297.

132 Griendling KK, Sorescu D, Ushio-Fukai M. NAD $(\mathrm{P}) \mathrm{H}$ oxidase: role in cardiovascular biology and disease. Circ Res 2000; 86: 494-501.

133 Bokoch GM, Knaus UG. NADPH oxidases: not just for leukocytes anymore! Trends Biochem Sci 2003; 28: 502-508.

134 Shmelzer Z, Haddad N, Admon E, et al. Unique targeting of cytosolic phospholipase A2 to plasma membranes mediated by the NADPH oxidase in phagocytes. J Cell Biol 2003; 162: 683-692.

135 Weissmann N, Voswinckel R, Hardebusch $\mathrm{T}$, et al. Evidence for a role of protein kinase $\mathrm{C}$ in hypoxic pulmonary vasoconstriction. Am J Physiol 1999; 276: 90-95.

136 Matsuzaki I, Chatterjee S, Debolt K, Manevich Y, Zhang Q, Fisher AB. Membrane depolarization and NADPH oxidase activation in aortic endothelium during ischemia reflect altered mechanotransduction. $A m ~ J$ Physiol Heart Circ Physiol 2005; 288: 336-343.

137 Petheo GL, Demaurex N. Voltage- and NADPH-dependence of electron currents generated by the phagocytic NADPH oxidase. Biochem J 2005; 388: 485-491.

138 Henderson LM, Chappell JB, Jones OT. The superoxidegenerating NADPH oxidase of human neutrophils is electrogenic and associated with an $\mathrm{H}+$ channel. Biochem J 1987; 246: 325-329.

139 Jones RD, Hancock JT, Morice AH. NADPH oxidase: a universal oxygen sensor? Free Radic Biol Med 2000; 29: 416-424.

140 Mohazzab KM, Wolin MS. Sites of superoxide anion production detected by lucigenin in calf pulmonary artery smooth muscle. Am J Physiol 1994; 267: 815-822.

141 Gabig TG, Bearman SI, Babior BM. Effects of oxygen tension and $\mathrm{pH}$ on the respiratory burst of human neutrophils. Blood 1979; 53: 1133-1139.

142 Thomas HM3, Carson RC, Fried ED, Novitch RS. Inhibition of hypoxic pulmonary vasoconstriction by diphenyleneiodonium. Biochem Pharmacol 1991; 42: 9-12.

143 Grimminger F, Weissmann N, Spriestersbach R, Becker E, Rosseau S, Seeger W. Effects of NADPH oxidase inhibitors on hypoxic vasoconstriction in buffer-perfused rabbit lungs. Am J Physiol 1995; 268: 747-752.

144 Majander A, Finel M, Wikstrom M. Diphenyleneiodonium inhibits reduction of iron-sulfur clusters in the mitochondrial NADH-ubiquinone oxidoreductase (Complex I). J Biol Chem 1994; 269: 21037-21042.

145 Weir EK, Reeve HL, Cornfield DN, Tristani-Firouzi M, Peterson DA, Archer SL. Diversity of response in vascular smooth muscle cells to changes in oxygen tension. Kidney Int 1997; 51: 462-466.

146 Jones RD, Thompson JS, Morice AH. The NADPH oxidase inhibitors iodonium diphenyl and cadmium sulphate 
inhibit hypoxic pulmonary vasoconstriction in isolated rat pulmonary arteries. Physiol Res 2000; 49: 587-596.

147 Weissmann N, Tadic A, Hanze J, et al. Hypoxic vasoconstriction in intact lungs: a role for NADPH oxidase-derived $\mathrm{H}(2) \mathrm{O}(2)$ ? Am J Physiol Lung Cell Mol Physiol 2000; 279: 683-690.

148 Ichinose F, Ullrich R, Sapirstein A, et al. Cytosolic phospholipase $\mathrm{A}(2)$ in hypoxic pulmonary vasoconstriction. J Clin Invest 2002; 109: 1493-1500.

149 Archer SL, Reeve HL, Michelakis E, et al. $\mathrm{O}_{2}$ sensing is preserved in mice lacking the gp91 phox subunit of NADPH oxidase. Proc Natl Acad Sci USA 1999; 96: 7944-7949.

150 Archer SL, Weir EK, Reeve HL, Michelakis E. Molecular identification of $\mathrm{O}_{2}$ sensors and $\mathrm{O} 2$-sensitive potassium channels in the pulmonary circulation. Adv Exp Med Biol 2000; 475: 219-240.
151 Michelakis ED, McMurtry MS, Wu XC, et al. Dichloroacetate, a metabolic modulator, prevents and reverses chronic hypoxic pulmonary hypertension in rats: role of increased expression and activity of voltage-gated potassium channels. Circulation 2002; 105: 244-250.

152 Aaronson PI. Hypoxic pulmonary vasoconstriction is/is not mediated by increased production of reactive oxygen species. J Appl Physiol 2006; 101: 1000-1005.

153 Camello-Almaraz C, Gomez-Pinilla PJ, Pozo MJ, Camello PJ. Mitochondrial reactive oxygen species and $\mathrm{Ca}^{2+}$ signaling. Am J Physiol Cell Physiol 2006; 291: C1082-C1088.

154 Duszynski J, Koziel R, Brutkowski W, Szczepanowska J, Zablocki K. The regulatory role of mitochondria in capacitative calcium entry. Biochim Biophys Acta 2006; 1757: 380-387. 